\title{
Spatial culture, processional culture and the materialities of social memory in nineteenth-century Sheffield
}

\author{
Dr Sam Griffiths, Space Syntax Laboratory, UCL Bartlett School of Architecture, University College London \\ sam.griffiths@ucl.ac.uk
}

\begin{abstract}
Dr Sam Griffiths is Lecturer in Spatial Cultures in the Space Syntax Laboratory at UCL's Bartlett School of Architecture. His theoretical and empirical research focuses on understanding the built environment as an aspect of the socio-economic and cultural history of cities and suburbs, with a focus on nineteenth-century British industrial cities. He is also interested in how architectural ideas are encoded in literary and historical works. He is co-editor with Alexander von Lünen of Spatial cultures: new perspectives on the social morphology of cities past and present, due to be published by Routledge in May 2016.
\end{abstract}

\begin{abstract}
This article presents research about a wide range of processions and crowd activities in the English industrial city of Sheffield c.1790-1910. It identifies a theoretical weakness in the historical scholarship where an emphasis on the role of procession and protest in symbolically ordering the built environment too often serves to represent it as intrinsically un-ordered and lacking in definition. The effect, it is argued, has been to present symbolic regimes, particularly those of local elites, as something imposed on rather than, in any sense arising from quotidian urban performance and to artificially isolate research into processional and other mass-participation activities from the shared material context of a city's spatial culture. The notion of spatial culture is developed with reference to the work of Bill Hillier, Manuel De Landa and Henri Lefebvre, among others, to propose an interpretative 'mapping' of the relationship between the evolving structure of Sheffield's built form and the development of its processional culture. The research raises the question of how far civic traditions often regarded as 'inventions' in fact arose from the material conditions of urban life itself, in that sense revealing the historicity of social memory.
\end{abstract}

Keywords: processions, processional culture, spatial cultures, Sheffield, Bill Hillier, rhythmanalysis, social memory

Submitted to the special issue: 'Crowds, Protests, and Processions: Revisiting Urban Experiences' 


\section{Introduction}

This research concerns that subset of crowd activities that can be loosely classified as 'processional', as these developed in the English industrial city of Sheffield over the nineteenth century. A minimal definition of the term 'procession' is adopted to refer to the collective movement of 'processionists', with at least a notional common purpose and degree of formal organization, through a given passage of urban space typically designated in advance as a 'route'. This broad definition extends the term 'procession' to include alternative categories of collective urban movement such as: parade, 'march', and 'demonstration'. As a consequence, the range of processional activities covered varies widely with regard to: size and scale; the balance of processionists and spectators; the involvement of elite and popular participants, and the presence of formal and spontaneous elements. These apply across a wide spectrum of events: from the exuberant celebrations of electoral franchise reformers to solemn public funerals; from mass-participation 'Whit Sings' to the fantastic spectacles of royal visits, and from politically charged Chartist protests to the leisured entertainment of suburban horse shows.

The focus of this research then, is decidedly not on the minute classification of diverse processional types, so much as with understanding the emergence of what the historian Simon Gunn $(2000,231)$ has described as an urban 'processional culture' of the nineteenth century city. It explores the proposition that the reshaping of quotidian movement space in Sheffield, as a consequence of the urbanization associated with Britain's 'industrial revolution', gave rise to new possibilities of symbolic expression for crowd activities, as these took an increasingly processional form. Approached from this broadly materialist perspective, the phenomenon of urban processions presents an opportunity to explore empirically, through historical research, the sociological problematic of the relationship between built form (i.e. how the city 'works' as a spatio-functional entity) and urban culture (i.e. how the city 'means' or 'comes-to-meaning' as a social entity). A number of recent historical studies have provided useful accounts of the material context of urban processions (for example Georgiou 2016; Vari 2013; Vandeweghe 2011; Favro and Johanson 2010; Fassler 2007) but these still leave the crucial question of the material agency of the city, with regard to the production of its social, political and cultural symbols, rather under-conceptualized (though see Nejad 2013). In examining how the material organization of Sheffield served to differentiate urban sites according to their potential for the symbolic expression of different processional types, my 
intention is to theorize Sheffield's processional culture as a symbolically productive dimension of its spatial culture.

The concept of 'spatial culture' can, of course, be applied to geographical locations and historical periods other than the one selected here (see Griffiths and Von Lunen 2016). It is a term with broad interdisciplinary resonance, able to draw the humanities and social sciences into a dialogue with architectural approaches to what Penn (2003) has called the "shape of habitable space", as well with a range of perspectives from the social theory and anthropology of space (Griffiths and Netto 2015). There are several reasons why a case study of Sheffield is well suited for engaging with this conceptual frame. Sheffield's nineteenth-century past as an 'industrial city' associates it with a period of paradigmatic social change, in which the expansion of the built environment was accompanied by an increased level of processional, as well as economic, activity. The concept of 'spatial culture' articulates these socio-economic developments as being productive of a dimension of spatial practice in which material and semantic domains were dynamically negotiated (Griffiths forthcoming).

Approaching processional activity from a spatial cultures perspective necessarily blurs categorical distinctions between quotidian and ceremonial performative modes, yet it does not collapse such distinctions altogether. Rather it raises the possibility of 'mapping' as an interpretative method in which the material conditions of everyday life are written-in through a process of reflexive engagement with historical sources, rather than projected-on through the unreflexive use of, for example, maps and plans as illustrative representations; these can do little, in themselves, to bridge the epistemological gap between the materiality and meaning of events. In spatial cultures such sources are regarded as hermeneutical (though not necessarily 'textual') objects for 'the writing of maps and the spacing of writing' (Griffiths and Von Lunen 2016, xxvi). This defines the terms of an empirical enquiry into the entanglement of material formations and semiotic codes that resists resolving one set of descriptions into the other, for example in accounts of social practice or performance. In spatial cultures research 'mapping' narrates a particular figuration of what De Landa (2000) refers to as 'non-linear' history, in which the precise meaning of processional events (for example) are acknowledged as historically contingent or (after Derrida 1982) temporally 'deferred'. 
Following the introduction, the argument proceeds in four principal stages. Firstly, the concept of urban 'spatial cultures' is developed in the specific context of neglected epistemological questions raised by the historiography of British industrial cities. Secondly, an account of the morphological history of nineteenth-century Sheffield summarizes a range of infrastructural events and spatial practices that, it is argued, served to encode the city's spatial culture materially. Thirdly, this analysis provides the basis for a comprehensive account of the emergence of Sheffield's nineteenth-century 'processional culture' as a heterogeneous set of symbolic strategies, deployed by different social groups for a variety of reasons, and making different claims on the city's built environment. The concept of spatial cultures is here used to decode the symbolic order 'imposed' by processional activities on Sheffield's urban space, by identifying four distinct phases in which these strategies can be 'mapped' as particular symbolic expressions of the spatial practices of the quotidian city. The fourth stage focuses on the succession of public funerals in Sheffield to argue that admitting the material dimension of processional culture highlights a need to reconsider the assumption that communal memory is largely a language-based, immaterial or 'imagined' phenomenon (after Anderson 1991). As Bender (2010,319) comments, the "urban imaginary does not arise arbitrarily or out of nothing" but is a material, networked process of meaning as well as a representation. Finally, some reflections on the broader implications of the theoretical and empirical strands of the research are presented in the conclusion.

\section{The spatial culture of industrial cities: historiographical and theoretical preliminaries}

\section{A The historiographical-epistemological context}

Despite the weight of research in urban and social history that touches on the phenomenon of nineteenth-century British 'industrial' cities, the apparently straightforward fact of the rapidly increased quantity of urban space in which social life took place remains strangely undeveloped conceptually. Perhaps because interest in urban material configurations and Durkheiminan social morphology has waned since the formative days of urban history, or perhaps because works of nineteenth-century history conventionally preface their main theme with an adjectival nod to 'rapidly growing' manufacturing centres, it has become all too easy to put a gloss on the profound material transformation this process involved. A tendency to reductionist explanatory frameworks, whether socio-economic (Marxian) or cultural (revisionist) in the historiography of the nineteenth-century city highlights the epistemological problems that follow from this weak conceptualization of city-space. As Colin Pooley (2000: 
465) notes, the social theory of space has done little to move research into the relationship between urban structure and everyday life far beyond the realm of speculation. The 'spatial turn' in the social sciences and humanities has been more successful in exploring the social significance of spatial representations than spatial materialities (Kingston 2010; Biernacki and Jordan 2002; Gunn and Morris, 2001). Research in this area is epistemologically hamstrung by a dominant conceptual model that seeks, after David Cannadine (1982), to directly map 'shapes on the ground to shapes in society'. Yet without a theory of what the shape of social space is or what it does, these attempts resembles little more than static snapshots of socioeconomic processes. The situation has led one historian of urban street life to question whether 'space matters' at all in historical epistemology (Jerram 2013).

This epistemological problem of urban materiality is compounded in relation to the historiography of English industrial cities in the nineteenth-century where the influence of a long tradition of social reform and planning discourse often serves to conflate the places where people lived and worked with the environmental degradation and social immiseration that characterized many poorer areas (Mayne and Murray 2001; Hunt 2004, 321). Lewis Mumford $(1961,515)$ is typical in describing the industrial city as a largely chaotic realm, a "blasted, de-natured man-heap" devoid of agency to create human meaning. This emphasis implicitly (and sometimes explicitly) tends to represent the urban built environment either as un-ordered in the sense of 'chaotic', or dis-ordered in the sense of degrading an earlier form of order - and therefore ready for the imposition of symbolic discipline. The influence of this discourse is evident in the historiography of processional culture in industrial cities. Harrison, for example, contrasts the relatively 'entrenched environment' of Bristol with the 'chaotic' one of Manchester where, he argues, crowd activity was impeded by the 'compartmentalised, fragmented and contingent environment of the emerging industrial city' (Harrison 1988, 56). Similarly, Gunn argues that the processional culture of nineteenth-century industrial cities 'served to stamp a symbolic 'image' on what were increasingly distended and amorphous cityscapes' that gave substance to an idealised vision of the urban community 'set against the disorganisation of the city' (Gunn 2000, 230, 238). Peter Goheen (1993) is typical in regarding the built environment as little more than a platform for particular buildings of symbolic significance. This emphasis isolates research into the semiotics of massparticipation processional events from the shared material context of urban life, presenting the 
former in rather abstract terms as 'invented traditions' (Hobsbawm and Ranger 1992) without exploring the role of quotidian materiality in symbolic production.

\section{B. Spatial cultures theory}

The theory of spatial cultures problematizes any assumption of a straightforward, linear, translation between functional definitions of social space and the meaningfulness of 'place' that, depending on one's starting point, usually results in the erasure of one definition or the other (Gieryn 2000). It works with descriptions of the material world, be these cartographical, architectural, morphological, networked, visual or textual but does not seek to directly tie these with conventional categories of social analysis such as class or gender. It therefore asserts a degree of agency for 'habitable space' that is not acknowledged in its semiotic representations.

The theory of urban spatial cultures was initially proposed by the architectural theorist Bill Hillier (1989), having previously been developed in the context of complex buildings research by Hillier's PhD student John Peponis (Peponis 1985). Both drew on a tradition of space syntax research dating back to the early 1970s (see for example, Hillier et al 1976. Hillier $(1989,6)$ argues, with strongly Durkheimian overtones, that the spatial morphology of a society is "not simply a function of the principles of the social reproduction: it is an intrinsic aspect of it, a necessary part of the social morphology". ${ }^{1}$ In other words a society's spatial form is agential in the genesis of its social solidarities, rather than derivative of anterior socioeconomic forces, as is it is typically regarded in post-quantitative, Marxian, human geography (Hillier 2008; Soja 2001; Harvey 1973). Hillier's 'social' theory, built around the formal proposition of 'space syntax,' has, however, been developed in a strongly structuralist framing that creates problems when seeking to engage with questions of historicalsociological research (Griffiths 2012; also Weissenborn 2015). For Hillier physical forms and social rules operate at well-defined micro- and macro- scales to form a organismic whole and he shows little interest in social practices that do not conform to a well-defined (one might say 'closed') social totality. As a consequence Hillier rarely seeks to articulate the complex

\footnotetext{
${ }^{1}$ Although it would be misleading to describe Hillier as a straightforward 'Durkheimian', a Durkheimian concern with social solidarity is a recurrent and formative theme in the development of the more explicitly 'social' theory aspects of space syntax research (Hillier et al, 1976; Hillier and Hanson 1984; Hillier and Netto 2002, Hillier 2008). Hillier and Hanson (1984, 223) argue that the "physical arrangement of space by societies is a function of the forms of social solidarities" See also Liebst (2014; 2016).
} 
temporalities of historical space or its inherent ambiguity in relation to questions of sociospatial practice and the production of meaning (Griffiths 2011; Netto 2016).

A key insight of space syntax theory that belies its structuralist framing, however, is that spatial morphology cannot be reduced to a function of abstract socio-economic processes. No matter how much social control is imposed the possibility for space to 'speak back' as a field of movement and encounter is always present (Hillier et al 1976, 180). Space, as Hillier (1989, 6) puts it is 'used sometimes to generate and sometimes to restrict the field of encounter of human beings and their symbols'. This definition has echoes of Henri Lefebvre's notion of 'representational space' as 'lived', at least in Hillier's (1996, 170) minimal sense of 'used space', where symbolic regimes and spatial practice are negotiated. For Hillier the spatial encounter field is governed by social-morphological rules (wherein lies its agency), as well as ideological norms, that define what space does to perpetuate sociality. Since these rules are syntactical rather than semantic they resist attempts to define spatial 'meaning' referentially. Spatial culture is thus 'a distinctive way of ordering space so as to produce and reproduce not actual social relations [...] but the principles for ordering social relations' (Hillier 1989, 6). These principles do not privilege the individual subject or body but are constructed allocentrically $^{2}$ and extrasomatically ${ }^{3}$ as configurational descriptions that encode the material organization of inhabited space (for example, in buildings or street networks) . For Hillier then, space is the agency through which individuals collectively enact society. It has no existence, whether as a cognitive blueprint or cultural representation, anterior to its realization in space and time.

Hillier's insistence on the social agency invested in the material world, rather than the symbolic domain of language, invokes parallels with the relational ontologies of actornetwork theory (Latour 2005) and assemblage theory (De Landa 2006); theories that emphasize the description of the external relations between agents and the decentring of individual subjectivities. Both share a concern to bridge the binary domains of material and the semantic by presenting the agency of the material in affording meaning as prior to the

\footnotetext{
${ }^{2}$ The Oxford English Dictionary offers the following definition of 'allocentric': 'Concentrating on or interested in external objects in themselves, rather than in regard to their relation or relevance to oneself', http://www.oed.com/ (accessed March 9, 2016).

${ }^{3}$ The Oxford English Dictionary offers the following definition of 'extrasomatic': 'Deriving from or referring to events external to a person considered as an individual or as a member of society', http://www.oed.com/ (accessed March 9, 2016).
} 
construction of the established categories of sociological analysis. These perspectives raise the question of the social-morphological logic of architecture, which, as Christian Borch $(2008,557)$ notes, 'remains a rather unexplored topic in much social theory'. Borch advances Peter Sloterdijk's notion of 'foam architecture', as giving a specific material form to the phenomenological conception of 'atmospheres', denoting architecture as a rich perceptual source of social affect, that 'cannot be reduced to any individual' (561). Interestingly, the sociologist Lasse Liebst has advanced what he calls a 'postephenomenological' perspective on the atmospherics of urban space, in dialogue with space syntax theory. According to Liebst, this entails a shift from an aesthetics-driven focus on urban 'physiognomy' to morphological accounts of spatial configurations that condition social affect by meditating the flow of human densities.

Current sociological interest in how mobilities and communications infrastructure constitute social practices (Urry 2007, Shove, Pantzar and Watson 2012) have also made it easier to think about the 'network effects' of built environment morphology in similar terms, without asserting a functionalist organismic totality. De Landa (2006, 94-99), for example, raises the importance of infrastructural connectivity on the development of urban neighbourhoods. Yet, perhaps surprisingly, his conceptualization of the social city is basically an interactionist one, heavily influenced by Anthony Giddens' $(1984,375)$ notion of the locale as a 'setting for interaction'. Yet the locale itself is largely abstract in definition (and devoid of agency) in Giddens' structuration theory. This is perhaps because of Giddens conceptual reliance on Torsten Hägerstrand's time geography to frame the idea of situated practices. ${ }^{4}$ The basic analytical unit in time geography is individual routines, making it difficult to conceptualize the collective, material, dimension of social experience that persists in the absence of any given individual.

Hillier (1996, 212-14) addresses this important question through the notion of the "virtual community" which asserts the essential intelligibility of spatial practice as descriptions of social information encoded configurationally in the built environment prior to any actual social interaction taking place. These descriptions, he argues, anticipate particular 'pull factors' in shaping the encounter field - in other words the configuration of space is its own attractor. This proposition underlies Hillier's (1996: 222) differentiation between the street

\footnotetext{
${ }^{4}$ See Pred (1977) for some interesting reflections on Hägerstrand and time-geography
} 
axis used instrumentally to stimulate co-presence, social interaction and commercial exchange (for example in the City of London), and symbolically, where a dominant axis is used to emphasize the social power invested in key buildings (for example Versailles). The former, associated with social production, is generative of what Hillier et al $(1976,180)$ refer to as 'profane' social mixing, the second, associated with social reproduction, is conservative, and in that sense ideological. Hillier's 'virtual community' then, is the materialized dimension of society that encodes the actual community of discrete individuals in time.

Paradoxically, Hillier's analytical epistemology employs a largely binary model of scale (local and global) that serves to eliminate temporal texture from urban space. This causes difficulties for historical research since, if a given social practice might be associated with a given historical scale of spatial practice, any urban culture can expect to contain an almost infinite diversity of such practices performing urban space at different scales. Scale, in other words, by differentiating space-as-practiced at a given time from the totality of time-space, articulates a distinctive spatial modality of practice that is also a temporal framing of space. In this respect De Landa's emphasis on assembling social reality at multiple interpenetrating scales of social organization (individuals, institutions to cities and nations) usefully deprivileges the observer's static position and helps to reveal how spatial practice may also be regarded as an expression of the material intelligibility of society, at modalities of scale other than that which conforms to the representation of a particular social archetype.

In space syntax theory the concept of 'intelligibility' has a particular analytical definition: the extent to which the local properties of the urban grid are indicative of urban-scale structures (Hillier 1989). Yet Hillier's definition of intelligibility is not simply pragmatic. It advances a fundamental premise that would-be unifying social ideas (as aspatial abstractions) must find a mechanism to realize themselves in the material world at the largest possible scale. This means that, no matter how little industrial cities resembled archetypal 'ceremonial cities' with their strong symbolic axes, in an era before electronic mass communication it was still the built environment that was the essential medium through which elite symbols were promulgated. Hillier's notion of local-to-global urban 'intelligibility' therefore, raises the question about the material domain in which the (urban) medium shapes the message. It suggests a role for spatial cultures research in exploring the historical relationship between the materialities of spatial practice and the practice of cultural representations. 
De Landa notes how the daily rhythms of collective movements such as journeys to work and trips to the shops can manifestly influence the material development of cities (for example in producing patterns of connectivity). Yet he also notes how such urban rhythmicity 'seems to present a problem' for assemblage theory since these patterns emerge over such long time spans that they cannot easily be assigned to purposive actions of individual agents (De Landa $2006,95)$. The admission is indicative of the limitations of assemblage theory with regard to the explication of morphogenesis processes. On the whole, actor-network descriptions of material agency employ discursive (i.e. language-based) techniques to trace well-defined relationships of effect and affect. In spatial cultures theory, however, the plasticity of urban space should not be conceived only in referentially (such that that repeated journeys across a field might impress a path where people sometimes meet) but also non-discursively (i.e. configurationally), such that the connection (or relation) so created has consequences for the encounter field that are essentially unpredictable as to social outcomes. This highlights the potential of a given urban space to afford social intelligibility at more than one scale of practice - without necessarily incurring any material change - depending on its configurational description. The temporality of morphogenetic processes suggests how different generations and social groups may, in fact, practice the same (material) space differently because of the wider set of spatial and non-spatial (i.e. conceptual) relationships in which any given space becomes historically and materially embedded.

Lefebvre, in Rhythmanalysis refers to 'dressage' as the routine performance of bodies in everyday life. Although highly constrained by social conventions of bodily discipline dressage is an essential social resource because the material and historical circumstances of bodily routines are 'never exactly and absolutely the same'. Lefebvre argues that dressage 'determines the majority of rhythms' (Lefebvre 2004, 40). It follows that 'public (therefore social) rhythms' (including ceremonial and celebration) are not divorced from the practice of dressage but interpenetrate with everyday life' (18). This invokes the sociologist Randall Collins' (2004) argument that society is enacted on a quotidian basis as 'chains' of ritualized interactions between human bodies rhythmically orientated towards other bodies.

Interestingly, Liebst (2014, 109-10) invokes Collins' micro-sociological argument to develop his critique of what he sees as Hillier and (Julienne) Hanson's essentially macro-sociological, that is structuralist, position in The Social Logic of Space (1984). Liebst argues that this does 
not go far enough in explaining how the spatial morphology of a society contributes to translating the simple fact of spatial co-presence of bodies into a situation generative of social solidarity. As anthropologists have noted, rituals are as much about intuitive bodily performance and spatial orientation as they are about their specifically discursive content (Parkin 1992; Connerton 1989). In this respect processional culture is paradoxical since as ritual performances, processions are attempts to fix certain scales of spatial practice as normative and in that sense render them ahistorical. In the rapidly changing social and material environment of the industrial city the tension between processional practices symbolizing continuity and change can be expected to be particularly acute

This argument has particular resonance to the ascendant middle classes of the nineteenth century. Lefebvre $(2004,14)$ claims that: 'Objectively, for there to be change, a social group, a class or caste must intervene by imprinting a rhythm on an era' (for which we can fairly substitute 'city'). The act of 'imprinting' (not the most helpful term with its textual connotations), for example, by dictating the route and symbolic content of a procession does not, however, take place in a performative void since any nascent social class or generation is socialized in the dressage of its predecessor. The emergence of a processional culture in the industrial city itself represented an 'intervention' (or a succession of interventions) by middle class urban elites for whom 'dressage' was the 'raw material' of symbolic production. Hillier and Hanson $(1984,45)$ argue that the social information encoded in the built environment needs to be 'constantly re-embodied in social action if [society] is not to vanish or mutate'. Yet it is precisely the process of mutation that needs explaining historically. In this respect Hillier's $(1989,20)$ speculation that ' the concept of 'intelligibility' opens up some of the configurational dimensions of urban memory' is useful because the possibility of a sociospatial mnemonic (largely redundant if nothing changed) makes sense where developments in urban spatial culture (largely non-discursive, everyday spatial practices) become the object of discursive reflection, for example, as they inflect on shifts in processional culture.

Space for Lefebvre is an essentially historical production: he asks 'what is a centre, if not a producer of rhythms in social time?' (Lefebvre 2004, 98). The temporal description of spatial culture in these terms is appealing in allowing not only for what Lefebvre would call the 'polyrhythmia' or diversity of rhythms characteristic of urban life but also for the notion that 
such multiplicity arises from interplay of the quotidian rhythms of everyday life and the public 'rhythms of representation', including processions and celebrations, with which it is punctuated. Lefebvre (95) emphasizes that between these two poles there are 'multiple transitions and imbrications' - suggesting the existence of a complex scaled dynamic between bodily intimacy, the material world of social practice and scripts of social power that are negotiated, contested and sustained in lived space. Lefebvre argues that his rhythmical conception of social time also describes historical time. He conceives of this in terms of the tension in a capitalist society between a past that is periodically destroyed but then represented both as history (as historians may write it) and as nostalgia (in popular culture). Both these senses have relevance to the interpretation of Sheffield's processional culture as a spatial culture and repository of social memory.

\section{The morphological history of processional culture in Sheffield}

The population of central Sheffield Township rose from 31,314 in 1801 to 83,428 in 1851 before levelling out. The rate in Sheffield Parish (including the outlying townships of the city) rose from 135,310 in 1851 to 380,793 in 1901, as a consequence of extensive suburban growth in the second half of the nineteenth century. This demographic expansion precipitated a huge transformation of Sheffield's built environment. In Griffiths (2009), I show how Sheffield's urbanization was characterized configurationally by a series of transitions from a relatively sparse nucleated circulatory structure in the early nineteenth century, to an extended area of dense spatial proximity by the mid-nineteenth century, to the emergence of strong linear structures along historical routes connecting the late nineteenth century web of suburban centres, what Hillier (2009) would call a "foreground network", to the central township. Space syntax analytical techniques were used to identify the relative proximity, circuitousness and linearity of road elements. This analysis revealed the multi-dimensional complexity of configurational descriptions, particularly in relation to the 'deep' structure of the historical road network. This complex but intelligible morphological structure strongly suggests that it is misleading to describe Sheffield as an 'amorphous' or 'chaotic' industrial city.

Griffiths (2016) deploys these configurational descriptions in hermeneutical mode to interpret changes in the relationship of home and work and the location of processional routes in Sheffield over the nineteenth century as emergent spatial practices. Analysis of journey-to- 
work data suggested how the middle classes of the early twentieth-century city exploited the globalizing properties of the network on a quotidian basis as the distance between home and work increased. This transition was conceptualized as affording the symbolic privileging of the 'global' (linearizing) modality of scale in Sheffield's spatial culture that associated bodily mobility with social mobility. This configurational affordance for scale plasticity was often realized materially over time, for example in the widening and straightening of historical road structures to create more efficient transport routes.

On the basis of this work it is possible to sketch what the anthropologist of ritual David Parkin $(1992,18)$ calls the 'formulaic spatiality' of processional culture in Sheffield with regard to route, orientation and directionality. This task is complicated by the context of a dynamic built environment that necessitated ongoing alterations to the 'idioms' of ritual of passage through urban space (17). In Sheffield it was noted that the successive rescaling of processional routes to perambulate an approximation to the main built-up area of the city centre increasingly gave way, from about the mid-nineteenth-century to a centrifugal 'original-destination' dynamic involving linear routes orientated outwards to suburban locations and employing open spaces such as parks, cemeteries and sports grounds as sites of ritual denouement. Such a finding does not, in itself, explain the wide range of symbolisms evident in Sheffield's processional culture but it does suggest that the argument that nineteenth-century urban elites 'invented' traditions is undermined to the extent that it fails to address the development of a city's processional culture in relation to the practice of its quotidian spatial culture.

There is still a need though, to provide an account of Sheffield's processional culture that attempts to 'map' the symbolic strategies deployed onto the symbolic possibilities occasioned by a spatial culture. The following two sections of this article presents such a 'mapping' in the form of an historical narrative. Drawing on empirical archive research the first section identifies four distinct phases in the development of Sheffield's processional culture as an aspect of its nineteenth-century spatial culture. These phases should be regarded as indicative trajectories rather than a strict chronological sequence since in reality there was considerable 
overlap. ${ }^{5}$ The first phase was focussed on the 'principal' streets of the early-modern city; the second sought to extend the idea of the perambulatory or circulatory procession of to the limits of the mid-nineteenth-century centre, the third describes the expansion of processional activity in distributed, suburban mode, and the fourth phase traces the emergence of 'suburban monumentalism'. The final section examines the tensions between processional performance as representations of continuity and change.

\section{Four phases in the development of processional culture}

\section{Phase 1: occupying the principal streets}

In late eighteenth and early-nineteenth century Sheffield civic and popular occasions typically took the form of relatively informal circulatory movement around the principal streets with processions beginning and ending at nearby public or semi-public buildings including the Parish Church, Town Hall, Cutlers' Hall, Tontine Inn and Assembly Rooms. Before the 1830s the phrase 'principal streets' was commonly deployed in the local press suggesting their identity was common knowledge. The eighteenth century bequeathed Sheffield a popular culture of street-based town feasts and the use of available open spaces such as churchyards for recreation, as for example during the Cutlers' Feast which was a three-day public holiday well into the nineteenth century (MacDonald 1997, 230). The relationship between public streets and public (and semi-public) buildings was key to the processional culture of late Hanoverian Sheffield, which was otherwise characterized by fairly unstructured street-based celebrations following the main processional event. This was evident, for example, when the town celebrated the centenary of the 'Glorious Revolution' (that established constitutional monarchy in England) in 1788. The celebrations lasted two days: the first marked by a procession of a number of the town's public bodies from the respectable Tontine Inn to the Parish Church for a crowded Service of thanksgiving, before processing back to the Tontine Inn for dinner marked by patriotic toasts and singing. Meanwhile, on the streets bonfires were lit and sheep roasted to the sound of firecrackers and the town's ringers parading with hand bells. The following evening a ball took place at the Assembly Rooms (for those with invitations) (Sheffield Register 8/11/1788). A similar combination of procession and the distribution of food was evident in radical fete held in November 1792 to celebrate the victory

\footnotetext{
${ }^{5}$ The sample of civic processions was compiled using keyword searches of the digitized Sheffield Local Register available in the Sheffield Local Studies Library that provides a useful chronicle of the dates of key events in Sheffield's history. These were cross-referenced with other local sources, principally newspapers.
} 
of French Republican armies (Sheffield Register 30/11/1788). Several decades later the victories of anti-Bonaparte forces in the Peninsular War in 1813 provided another good example of how the principal streets and public buildings combined to create shared moments of urban community. The Sheffield Mercury reported:

[t] he celebration commenced early in the morning by the bells ringing a merry peal, by loud reports answering each other from variously constructed fire arms, by the display of innumerable flags and devices, the lighting up of fires in the open streets [...] the roasting of sheep, public processions, \&c. \&c.

Dinners and toasts were held in various venues around the town that, that according to the report, were enjoyed by all social grades "statesman, merchant, manufacturer and mechanic" (Sheffield Mercury 11/12/1813). The end of the Peninsular War in 1814 was similarly the occasion of a procession around the central area and was marked with illuminations in which residents of the principal streets would light their lamps, sometimes creating extravagant displays in their windows (Sheffield Iris 5/7/1814). While the town's collective spatial culture was focussed on its principal streets, social distinctions were maintained by differential access to public buildings and affiliation to different drinking establishments.

\section{Phase 2: extending the symbolic boundary}

The ancient annual ceremony of perambulating the Parish boundary at Rogationtide (also known as 'beating the Parish bounds') is an example of processional activity used not only instrumentally to establish a geographical boundary, but also symbolically to demarcate a (Christian) community. ${ }^{6}$ Andy Wood $(2014,277)$ notes how Rogationtide celebrated the "social and spatial unity of the Parish". There is nothing to connect this traditional rural practice with nineteenth-century urban processional culture. Yet in Sheffield, from the lateeighteenth to the mid-nineteenth century, the increasing elaboration of processional routes beyond the principal streets of the eighteenth-century city implies an ongoing dialogue between attempts to symbolically represent the unity of the urban community, and the constrained possibilities for such symbolic expression afforded by a geographically extended and morphologically complex built-up area .

\footnotetext{
${ }^{6}$ According to Wood $(2014,275)$ Rogationtide is traditionally celebrated on Monday to Wednesday of Ascenscion week.
} 
A key event in its development was the 1797 procession to open the General Infirmary. Although it was in some respects anticipated by the procession to open another piece of suburban infrastructure, the new Corn Mill, in 1795, it is likely that the General Infirmary opening was the first processional route to be specified in advance in the local press and the first civic procession to represent the body politic of the late-eighteenth-century town. It included the masonic lodges who were instrumental in raising the funds for the infirmary; the official bodies of the town and the 'useful institutions' such as benefit societies and sick clubs that were often organized around the city's trades. The processional route took in the principal streets but extended northwards of the early modern centre to the suburban fringe where the new infirmary was located. The Sheffield Iris reported that:

Independent of the persons who walked in the Procession, forming an immense train, that reached from the town to the Infirmary, many thousands of admiring and applauding spectators accompanied this magnificent spectacle. The whole was conducted with a propriety and decorum that reflect the highest honour on those who arranged and managed the whole. (Sheffield Iris 6/10/1797)

The description recalls Gerd Baumann's proposition that urban ritual performances implicate 'the other', that is the spectators, as participants (Bauman 1992). Although there were familiar eighteenth-century elements to the occasion, including a sermon at the Parish Church, dinner at the Angel Inn and a trip to the theatre reserved mainly for the civic elite, the 1797 procession marks a transition point in Sheffield's processional culture in celebrating the town's 'new men' and their ability to get things done. Many of those involved in raising the money through subscriptions, for example Doctor John Browne, would become central to the civic life of Sheffield in the late Hanoverian period.

The huge public procession for the passing of the Reform Bill in 1832, that gave Sheffield Parliamentary representation for the first time, marks a high point in the processional culture of pre-Victorian Sheffield. According to the Sheffield Independent it seemed as though the whole of the town and its suburbs was in the "public streets" for an occasion of "moral grandeur" (Sheffield Independent 23/6/1832). The procession was organized by Sheffield's Political Union that had also mobilized the campaign for reform, but it is interesting that 'some misunderstanding' had caused the Cutlers Company and other civic bodies to withdraw from the procession, implying possible concerns about the representation of the urban community by the reformers (Sheffield Independent 16/6/1832). The procession consisted of 
the Sheffield Political Union, 'Reformers of Sheffield', the secret societies and masonic lodges, the sick and benevolent Societies and representatives of the towns trades - despite the fact that most working-class members of these trades were excluded from the reformed franchise. The procession was reported as being two miles along and taking forty-five minutes to pass in its entirety. At its conclusion members of the Political Union (about 1500) continued to the Cricket Ground at Hyde Park for dinner. The route selected for the Reform Bill procession greatly extended previous routes to include the recently developed industrial areas to the north and south-west of the town. It marks the stage at which the notion of 'principal streets' begins to appear anachronistic and more generic terms such as 'public streets' and 'thoroughfares' are preferred in the press reporting.

The route taken for Queen Victoria's coronation procession in 1838 closely followed that for 1832 but extended still further west. The Sheffield Independent reported that the procession compared favourably with its predecessor: "Excepting the unparalleled procession [...] at the passing of the Reform Bill, we believe that so large a procession as this has never before been seen in Sheffield" (Sheffield Independent 30/6/1838). The day of procession was a public holiday and decorations and illuminations were on display throughout the town. The coronation of the Queen meant that all public and ecclesiastical bodies were represented including the thriving Sunday School Unions, the masonic orders and friendly societies. The report noted that people were dressed in their "holiday attire" and confessed that the enjoyment of holiday and pageantry probably explained the "glad faces" but that the occasion demonstrated nonetheless how the "public mind" of Sheffield had come to celebrate the benefits of limited monarchy. Following the procession there was a ball for civic dignitaries and their guests in the recently built Music Hall on Surrey Street and an evening soirée at the Cutlers' Hall.

The Coronation Procession of 1838 represents the limits of Sheffield's processional culture in its attempt to perambulate the main built-up area of the town while representing the full spectrum of public bodies. Subsequent processions that marked the fall of Sevastopol (October 1855) and then Peace (May1856) in the Crimean War, would take extensive but idiosyncratic routes, excluding much of the northern and western industrial areas of the city. The 1856 procession included all the offices of the reformed municipal council (Sheffield had gained a corporation in 1843) in addition to representations of military offices, pensioners and 
veterans. The Sunday schools, a selection of masonic lodges and temperance groups were also present but the friendly and sick societies were sparsely represented (Sheffield \& Rotherham Independent 31/5/1856). This was indicative of the increasing symbolic marginalization of Sheffield's traditional working-class organizations in the new corporate order. The rise in Chartism in Sheffield in the 1830s had certainly disrupted the more optimistic notions of the urban community proclaimed in earlier processions. It is telling that the Chartists' right to meet in Paradise Square, a centrally located open space traditionally used for public meetings, was disputed on the grounds that the Chartists represented only "one class of the community" in opposition to the others (Sheffield \& Rotherham Independent 17/8/1839).

The Crimean celebrations brings to a close the phase in Sheffield's processional culture focussed on all-purpose public streets as the principal site for symbolically representing the urban community to itself. By the 1830s processions around the historical centre had been largely superseded by increasingly complex processional routes designated in advance and advertised in the local press. In any case, the growing population of Sheffield Parish from the $1820 \mathrm{~s}$, much of it beyond the central township, made the proposition of perambulatory routes increasingly unsustainable as spatial mechanisms for symbolic representations of the 'social and spatial unity' of the urban community. This is not to fall back on the deterministic use of a 'rapidly growing city' as an explanation. Rather it asserts how the representation of Sheffield as an urban community was both enabled but also constrained by its dialogue with the material and quotidian dynamics of its spatial culture. In the second half of the nineteenthcentury the public streets of Sheffield would increasingly be made to serve the spectacle of large-scale processional routes terminating in large open spaces in suburban locations for the ritual denouement.

\section{Phase 3: suburban diversification}

Sheffield suburbanized rapidly in the second half of the nineteenth-century. Increasingly the historic centre of the city was not the sole urban locus but rather the primary centre amidst many smaller but growing suburban neighbourhoods. The proliferation of local centres coincided with the emergence of a distinctly centrifugal dimension of processional culture . This was most evident in the 'Whit Sing' celebrations held annually on the Whitsun Monday holiday. These involved Sunday School children and their teachers processing to nearby openair venues (the 'Whit Walk') where the singing of religious and patriotic songs would take 
place. Although only a minority of children attended Sunday school consistently they were genuinely popular institutions in Sheffield with $24 \%$ of all children under 20 (14, 919 scholars) recorded as attending on the day of the 1851 religious census (Smith 1982, 121). Earlier in the century Sheffield's Whit Sing took place centrally in the area near the Corn Exchange and from the 1860s in the larger Norfolk Park, but by the early twentieth-century the popularity of Sunday Schools in the suburbanizing city had given rise to an extraordinarily dispersed form of organization. In 1903 some 40,000 scholars (approximately 10\% of Sheffield's population not including the teachers or the massed ranks of spectators) were organized into neighbourhood clusters for processions converging at local parks and recreation grounds around the city (Sheffield Daily Independent 2/6/1903). Far from being a globalizing form of processional movement Whit Sings were a simultaneity of processional activity at the local scale, embodying the local catchment of church and chapel. The representation of the Sunday School unions in the 1838 coronation procession and subsequently, however, speaks to their institutional presence in Sheffield's urban life and of the importance of children in its processional culture in symbolizing the relationship of the city with God, monarch and nation.

Another effect of the suburbanization of Sheffield was the diversification of processional activity from varied representations of the urban community to the promotion of a range of religious, charitable, political or even leisure interests, an example of Baumann's 'ritual constituencies' (Baumann 1992, 113). The frequent use in the local press of the term 'demonstration' in this context suggests that the spectating 'other' was being invited to consume a particular message as much as participate in these occasions. This does not mean they were not popular. The 'Great Demonstration of Oddfellows' (1864) for example, involved the city's masonic lodges with their regalia processing from the centre of town to the suburban Botanical Gardens where almost 40,000 people passed through the gates, principally, it was reported, for the purpose of entertainment (Sheffield \& Rotherham Independent 12/7/1864). Similarly attention grabbing Lifeboat Demonstrations were fundraising events involving the transport of a lifeboat through the city and terminating at a suburban park such as the Botanical Gardens (1895) or Endcliffe Woods (1898). Church Parades of military volunteers and ex-volunteers was a way of raising funds for their subsistence while also connecting the city with its past, as in the 1894 parade of Crimean and Indian war veterans to suburban Ranmoor on the fortieth anniversary of the Crimean Battle of Inkerman. Other 
events such as the Cyclists Church Parade (from the 1890s) and the Inspections of the Boys Brigade (for example in Endcliffe Park 1901) were indicative of the emergence of a demonstrative 'muscular Christianity'.

The Sheffield Horse Show (from 1904), involved festival floats being paraded through the city to suburban Hillsborough Park. It was a occasion for leisure rather than the declaration of any symbolic purpose. Nevertheless, the extended processional routes through suburban neighbourhoods towards parks on the urban periphery had their own symbolic resonance by appropriating these globalizing movements for the purpose of leisure. Demonstrations that went against the grain of this sociospatial dynamic tended to be those critical of the status quo. For example evangelizing processions around central Sheffield by the Salvation Army (1882/ 83) and temperance campaigners (1906) met with greater or lesser degrees of resistance from the local population. Demonstrations by the unemployed (from 1887), suffragists (1908) and socialists (from 1904) were marginal to the suburbanizing processional culture of later nineteenth-century Sheffield, however potent their political message. Indeed the symbolism of these protests lay largely in their exclusion, sometimes by law, from occupying the principal streets of the city centre and the suburban parks that nurtured mainstream processional culture - such that their presence in these spaces identified them as subversive.

\section{Phase 4: suburban monumentalism}

Although the symbolic importance of Sheffield's historical principal streets and buildings did not significantly diminish during the city's late nineteenth-century suburbanization their situation relative to changing structures of quotidian movement certainly did. The increasing separation of home and work among the middle-classes and skilled labourers would have produced a substantial pedestrian flow on the historical access roads leading to and from the city centre. The arrival of horse-drawn (1876) and then electric (1898) trams involved major programmes of widening and straightening along many of the same roads and the addition of pedestrian facilities such as pavements, all which would have helped realize these routes as 'globalizing' structures of accelerated movement. Lefebvre $(2004,96)$ argues that "political power dominates or rather seeks to dominate space; whence the importance of monuments and squares". In late nineteenth-century Sheffield it was increasingly suburban public parks that realized the symbolic emphasis of power, by virtue of their size and accessible location at the end of processional routes that strung together the densified suburban neighbourhoods of 
the suburban Parish. The increasingly linear, foreshortening, nature of such movements at the urban scale of the late nineteenth-century city was emphasised by the promise of ritualistic catharsis at the journey's end, the realization of what Turner (1966) called 'communitas', a temporary realization of community in the shared ritual space of the public park where social differentiation was (at least partially) suspended (see also Hillier and Hanson 1984, 182).

Whereas lifeboat demonstrations and horse shows involved relatively little symbolic investment and served mainly to celebrate an emerging leisure culture, the phenomenon of royal visits to Sheffield allowed the full symbolic potential of the public parks as globalizing site of processional denouement to be realized. The first major royals to visit Sheffield were The Prince and Princess of Wales. Over the next 35 years there would be further visits by the Duke of Duchess of York (1895), Queen Victoria (1897), King Edward VII (1905) and the Prince and Princess of Wales (1909). All these royal visits involved processions with accompanying events in public parks playing an important role in making royalty visible to the urban population at large.

The occasion of the visit of the Prince and Princess of Wales to Sheffield in 1875 was the opening of Firth Park on land donated by industrialist and Mayor Mark Firth. The Pictorial World reported how all along the processional route triumphal arches (usually in a mock gothic style) were 'as plentiful as blackberries' (Pictorial World 77, no. 3, 21/8/1875). The lengthy royal procession consisted almost entirely of horses and carriage with no apparent representations from masonic lodges, friendly or sick societies. The procession to Firth Park involved the royal object of spectacle and spectators alike in slow movements through crowded streets towards a single ritual focus. Once in Firth Park itself the royal couple received a 21 gun salute and some 15,000 Sunday School children sang God Save the Queen (The Sheffield and Rotherham Independent, 17/8/1875). The second day of the royal visit included a visit to the works of Messrs Thomas Firth and Sons, a firm important to the manufacture of armaments for the British Empire, an occasion that symbolized Sheffield's importance to nation and Empire.

The visit of the monarch Queen Victoria to Sheffield in her Diamond Jubilee year 1897, nominally to open the New Town Hall, was on an altogether grander scale. Some 43,000 board school children took part in the ritual crescendo at Norfolk Park, a natural amphitheatre 
well suited to this purpose. The great 'Gathering of Children' demonstrated a sophisticated capacity for large-scale processional organization that had been developed for the Whit Sings. Unlike these distributed celebrations though, the royal visits of 1875 and 1897 privileged a single ceremonial site for the ritual performance. The local press reported how the children's voices seemed to:

blend in the quadruple theme of praise to their Maker, loyalty to their Sovereign, patriotism and the love of home. (Sheffield and Rotherham Independent, 22/5/1897)

Towards the end of the nineteenth century the symbolic balance of this quartet shifted notably towards monarch, nation and Empire, rather displacing the religiosity and local catchment of the early Sunday School movement. Most blatantly jingoistic (despite protestations to the contrary in the local press) were the Empire Day celebrations that took place in the early 1900s. In 1907 some 13,000 'youthful patriots' were reported as participants in an elaborately choreographed event in front of 40,000 spectators at Bramall Lane sports ground that involved the children holding green and red flags to form the letters 'God Bless our Empire'. The event was favourably compared to a 'great military review' with children organized into 'disciplined ranks' (Sheffield Daily Independent 25/5/1906). There is a clear sense that a particular era in the history Sheffield was passing when the local press reported in 1906 that: 'Whit-Monday has been ousted from its position of honour and in the future children's day will be Empire Day' (Sheffield Daily Independent 21/6/1907). The use of a sports stadium for this event, to which many of the children had been shuttled by tramcar, indicates how the processional element has largely been dispensed with, perhaps because no public bodies were directly implicated in its performance. The festivities of Empire Day required little more than a blank canvas on which to project a vision of imperial majesty to which the local context was largely secondary.

\section{Processional culture as social memory}

From the mid nineteenth-century until perhaps the 1890s a distinctive note of self-awareness becomes evident in the press coverage of processional culture. The local press, for example, established the 1855 celebration to mark the fall of Sevastopol in the Crimean War in an historical tradition of similar events: 'the illumination of 1855 shall be to the next generation what that of 1814 [at the end Peninsular War] is now to us' (Supplement to the Sheffield \& Rotherham Independent 6/10/1855). This increasing historical awareness comes into 
particular focus with public funerals, important civic events involving an official procession, a general cessation of business and the widespread wearing of mourning clothes (public mourning). The funeral in 1854 of the poet, newspaper editor and leading Sheffield figure James Montgomery was the occasion of the Independent newspaper reprinting the coverage of the opening of the General Infirmary in 1797 and the public funeral of its principal instigator Doctor John Browne in 1810 - to compare the current occasion with 'what our grandfathers did' (Sheffield \& Rotherham Independent 13/5/1854).

Browne's funeral in 1810 was the first 'public' funeral in nineteenth-century Sheffield, fascinatingly there appear to have been no public funerals throughout the eighteenth century. ${ }^{7}$ The funeral procession took place between his centrally located residence and the Parish Church with 'thousands' crushed into the churchyard (Sheffield Iris 17/4/1810). With the opening of the suburban General Cemetery in 1838 and the final closing of the Parish Churchyard in 1856, funeral processions would take mourners and spectators out of the city and along major roads access road running west of Sheffield (Ecclesall Road to the north and Cemetery Road to the South ) to the site of burial. This route allowed for the formation of extravagant funeral processions: a mile long in Montgomery's case with some160 carriages preceding the hearse. Major public funerals were reported in forensic detail in the local press. Litten (1998) has argued how provincial funerals in the nineteenth-century began to ape aristocratic practices. The presence of a 'hearse decorated with plumes and drawn by six horses' in Montgomery's funeral provides evidence of this tendency (Sheffield and Rotherham Independent 6/5/1854).

Awareness of the developing tradition of public funerals is demonstrated by local newspaper coverage of funerals, up to that of Mark Firth in 1880, that dutifully reference all previous funerals since 1810. The 1873 press coverage of the public funeral of the Vicar of Sheffield Canon Sale was prefaced by the remark that::

The years of Sheffield's public mournings are easily numbered. They are 1810, 1851, 1854, 1865 and now 1873.( Sheffield \& Rotherham Independent 27/9/1873)

\footnotetext{
${ }^{7}$ A survey of 105 funerals of Sheffield notables 1700-1810, drawing extensively on information from the digitized Sheffield Local Register, revealed no clear case of an officially 'public' funeral that took place in Sheffield
} 
The sequence of the public funerals of John Browne, Thomas, Sutton, James Montgomery, Wilson Overend, and Canon Sale omit the unofficial but nonetheless public funeral of the Chartist Samuel Holberry who had died in York prison in 1842. Clearly Holberry has been excluded from official civic memory which sought to present the urban community in an ideal middle-class image, but his unofficial 'public' funeral is representative in being the first to exploit the symbolic potential of the long processional axis to the General Cemetery from the town centre, adopted by public funerals 1854-1880. Having first rehearsed the sequence of dates the 1873 commentator goes on to comment:

True there was one other [public funeral] on $12^{\text {th }}$ August, 1616, when Gilbert, seventh Earl of Shrewsbury, who had died in the previous May, was laid in his tomb in that Parish church which witnessed yesterday's ceremony. That was a funeral indeed! [...]But we may fairly prefer our plain ceremonial of yesterday, nowhere as a pageant but pregnant with real feeling, to that ostentatious but empty mockery in which Garter King-At-Arms and Blue Mantle, and Rouge Croix, and Richmond displayed all the pomp of heraldry in honour of a poor dead noble, whom few bewailed and nobody lamented.

It is possible to detect some unease in the caricature of 1616 funeral, which is portrayed as a category of social activity completely incomparable to the contemporary funeral procession of Reverend Sale. Of course in many ways it was different, not least in the exact symbolism deployed. Nevertheless the detailed account betrays a nagging concern that Gilbert's funeral was perhaps not quite different enough for a late nineteenth-century commentator on a liberal newspaper to feel quite comfortable. An aspect, perhaps, of what Lefebvre's $(2004,8)$ characterize as "differences induced or produced by repetitions". The irony, of course, is that in many ways both funerals were equally elaborate, the representation of numerous civic bodies (and the 106 carriages) in 1873 would have seemed equally incomprehensible to the men of 1616. There was, however, an important difference. The aristocratic funereal of Gilbert $7^{\text {th }}$ Earl represented and reproduced the symbols of a regional, national and international aristocratic order that defined Sheffield's urban community not by place but by association with blood. The funerals of 1810-1910 were, by contrast, unequivocally those of Sheffield men who had deep personal ties with the city where they had made there names and in that respect their processions were representations of an ideal of urban community with which the deceased identified and to whose historic pantheon of notable public men they aspired to join. 
The construction of Sheffield's General Cemetery is a testament to Victorian civic pride and, near its highest point, the funeral monument of Mark Firth still overlooks the city. As a leading industrialist Firth was nationally important, not least for manufacturing the armaments of Empire, which explains why his wife received a personal telegram of condolences from the Prince of Wales (Sheffield Independent 3/12/80). Firth's funeral procession was, however, broadly consistent with that of his predecessors. The public funeral of his fellow industrialist and philanthropist Sir Frederick Mappin in 1910 though, marked a decisive transition in the symbolic representation of Sheffield's urban community in funeral processions. Mappin, was also a national figure and his vast funeral was a heavily official affair populated by a large number of office holders in the city's expanded administration (Sheffield was formally granted city status in 1893) and figures from the national Liberal Party - which is not to say the occasion did not draw large crowds of local people. When the $14^{\text {th }}$ Duke of Norfolk died in 1860 he received a six-line obituary in the local press. At Frederick Mappin's funeral the Duke of Norfolk attended 'as a personal friend of the late baronet and not in any official capacity'. The Lord Mayor of Sheffield, Earl Fitzwilliam was unable to attend but 'sent his carriages' (Sheffield Daily Independent 24/3/1910). At this point processional culture in Sheffield seems to have come full circle with processional practices serving to re-integrate the aristocratic order into a now mature bourgeois culture, whose symbols of nation and Empire transcended as much as represented the urban communities that had nurtured them. Similar 'globalizing' ideas could also be found in the ascendant symbolic regimes of socialism, suffrage and salvationism at the beginning of the twentieth century yet none of these was so readily embraced by a spatial culture of suburban monumentalism.

\section{Conclusion}

The research presented in this article has developed the interdisciplinary concept of spatial cultures in which architectural 'spatial thinking' on the materiality of the urban object has been brought to questions of meaning in the social sciences. It has advanced a conceptualization of Sheffield's processional culture as an uncertain process of translation from quotidian scales of spatial practice to normative scales of processional practice, and also as a process of mapping the historical plasticity of processional performance to symbolically particular appropriations of urban space. The historicity of Sheffield's spatial culture in which its processional culture was embedded has been emphasized, in that it admits of no linear mapping from 'space' to 'symbolic order' but rather insists on the ambiguity of symbolic 
possibilities in processional performance, since the intelligibility of social space cannot dependent be dependent on any given symbolic arrangement or any particular scale of spatial practice.

The spatial cultures approach to processional culture also gives useful theoretical framing to the question of whether elite narratives in the nineteenth-century city should be regarded as 'invented traditions', or whether they arose, in some sense, 'objectively' from the material conditions of urban life itself. The conclusion, of course, is that to an extent both positions are true: material (morphological-relational) and symbolic (referential) possibilities are equally entangled and negotiable in the lived 'representational space' of the city. If the rhythmical nature of processional culture compromised a source of social memory in nineteenth-century Sheffield, recording how that processional culture changed over time reveals how social memory itself has a rhythm and therefor a history - that is it is not, to borrow Michael Bentley's distinction, simply a 'story told' but also a 'story lived' (Bentley 2006, 354). Indeed in asserting that culture is lived materially and can neither be reduced to (nor separated from) that which is remembered and imagined, the proposition of spatial cultures asserts the agency of the past itself, in giving shape or figuration to its own representations. 


\section{References}

Anderson, Benedict. 1991. Imagined communities: reflections on the origin and spread of nationalism. London: Verso.

Baumann, Gerd. 1992. Ritual implicates 'others 'rereading Durkheim in a plural society. In Understanding ritual, ed. Daniel de Coppet, 97-117. London and New York: Routledge.

Bender, Thomas. 2010. Reassembling the city: networks and urban imaginaries. In Ignacio Farias and Thomas Bender, eds, Urban assemblages: how actor network theory changes urban studies. London: Routledge.

Biernacki, Richard. and Jennifer Jordan. 2002. The place of space in the study of the social. In The social in question: new bearings in history and the social sciences, ed. Patrick Joyce, 113-150. London and New York: Routledge.

Bentley, Michael. 2006. Past and "presence": revisiting historical ontology. History and Theory 45, no. 3: pp. 349-361

Borch, C. 2008. Foam architecture: managing co-isolated associations. Economy and Society 37, no. 4: 548-571.

Cannadine, David. 1982. Residential differentiation in nineteenth century towns: from shapes on the ground to shapes in society. In The structure of nineteenth century cities, ed. James H. Johnson and Colin Pooley, 235-281. London: Croon Helm.

Collins, Randall. 2004. Interaction ritual chains. Princeton, New Jersey: Princeton University Press.

Connerton, Paul. 1989. How societies remember. Cambridge: Cambridge University Press.

De Landa, Manuel. 2000. A thousand years of nonlinear history. Brooklyn: Zone Books. 
De Landa, Manuel. 2006. A new philosophy of society: Assemblage theory and social complexity. London: Bloomsbury.

Derrida, Jacques. 1982. Margins of philosophy. Chicago: University of Chicago Press.

Favro, Diane and Christopher Johanson. 2010. Death in motion: funeral processions in the Roman Forum. Journal of the Society of Architectural Historians 69, no.1: 12-37.

Fassler, Margot. 2007. Adventus at Chartres: ritual models for major processions. In Ceremonial culture in Pre-modern Europe, ed. Nicholas Howe, 13-62. Notre Dame, Indiana: University of Notre Dame Press.

Georgiou, Dion. 2016. Weaving patterns in the suburban fabric: carnival procession routes, mapping place and experiencing space on London's changing periphery, 1890-1914. In Spatial cultures: towards a new social morphology of cities past and present, eds Sam Griffiths and Alexander von Lünen, 95-113. London and New York: Routledge.

Giddens, Anthony. 1984. The constitution of society: outline of the theory of structuration. Cambridge: Polity Press.

Gieryn, Thomas. 2000. A space for place in sociology. Annual review of sociology 26: 463496.

Goheen, Peter. G. 1993. The ritual of the streets in mid-19 ${ }^{\text {th }}$ century Toronto. Environment and planning D: Society and space 11: 127-145.

Griffiths, Sam. 2009. Persistence and change in the spatio-temporal description of Sheffield Parish 1770-1910. Proceedings of the 7th international space syntax symposium, eds. Daniel Koch, Lars Marcus and Jasper Steen, 37:1-15. Stockholm: KTH Royal Institute of Technology.

Griffiths, Sam. 2011. Temporality in Hillier and Hanson's theory of spatial description: some implications of historical research for space syntax. Journal of Space Syntax 2, no.1: 73-96. 
Griffiths, Sam. 2012. The use of space syntax in historical research: current practice and future possibilities. Proceedings of the eighth international space syntax symposium, eds Margarita Greene, José Reyes and Andrea Castro, 8193: 1-26. Santiago: Chile: PUC.

Griffiths, Sam. 2016. From lines on maps to symbolic order in cities? Translating processional routes as spatial practice, Sheffield c.1780-1910. In Spatial cultures: towards a new social morphology of cities past and present, eds, Sam Griffiths and Alexander von Lünen, 76-94. London and New York: Routledge.

Griffiths, Sam. Forthcoming. 'Manufacturing innovation as spatial culture: Sheffield's cutlery industry c.1750-1900’. In I. Van Damme, B. Blondé, A. Miles (eds), Unscrewing the Creative City: The Historical Fabrication of Cities as Agents of Economic Innovation and Creativity. Abingdon, Oxford: Routledge.

Griffiths, Sam and Alexander von Lünen., eds, 2016. Spatial cultures: towards a new social morphology of cities past and present. London and New York: Routledge.

Griffiths, Sam and Vinicius M. Netto. 2015. Open syntaxes: towards new engagements with social sciences and humanities, guest editorial. Journal of Space Syntax 6, no. 1: i-v. http://joss.bartlett.ucl.ac.uk/journal/index.php/joss/article/view/242 (accessed March 14, 2016).

Gunn. Simon. 2000. The public culture of the Victorian middle class: ritual and authority and the English industrial city, 1840-1914. Manchester: MUP.

Gunn, Simon. and Morris, Robert. J., eds. 2001. Identities in space: contested terrains in the western city since 1850. Aldershot UK; Burlington US: Ashgate.

Harrison, Mark. 1988. Crowds and history: mass phenomena in English towns 1790-1835. Cambridge: Cambridge University Press.

Harvey, David. 1973. Social Justice and the City. London: Edward Arnold. 
Hillier, Bill. 1989. The architecture of the urban object. Ekistics 56, nos 334-335: 5-20.

Hillier, Bill. 1996 Space is the Machine. Cambridge: Cambridge University Press.

Hillier, Bill. 2008. Space and spatiality: what the built environment needs from social theory. Construction research and information 36, no. 3: 216 - 230.

Hillier, Bill. 2009. Spatial sustainability in cities: Organic patterns and sustainable forms. In 7th International Space Syntax Symposium, eds, Daniel Koch, Lars Marcus and Jasper. Steen. Stockholm: Royal Institute of Technology.

Hillier, Bill, and Julienne Hanson. (1984) The Social Logic of Space. Cambridge. Cambridge University Press.

Hillier, Bill, Adrian Leaman, Paul Stansall, and Michael Bedford. 1976. Space Syntax. Environment and Planning B 3: 147-185.

Hillier, Bill, and Vinicius Netto. 2002. Society seen through the prism of space. Urban Design International 7: 181-203.

Hobsbawm, Eric, and Terence Ranger, eds.1992. The Invention of tradition. Cambridge: Canto.

Hunt, Tristram. 2004. Building Jerusalem: The rise and fall of the Victorian city. London: Weidenfeld and Nicholson.

Jerram, Leif. 2013. Space: A Useless Category for Historical Analysis? History and Theory 52: $400-419$.

Kingston, Ralph. 2010 Mind over matter? History and the spatial turn. Cultural and Social History 7, no. 1: 111-121. 
Latour, Bruno. 2005. Reassembling the social: an introduction to actor-network-theory. Oxford: Oxford University Press.

Lefebvre, Henri. 1991. The Production of space. Trans Donald Nicholson-Smith. Oxford: Blackwell.

Lefebvre, Henri. 2004. Rhythmanalysis: space, time and everyday life. Trans Stuart Elden and Gerald Moore. London: Continuum.

Liebst, Lasse. S. 2012. Intensifying the atmospheric: a postphenomenological reappraisal of the ambiance of urban space. Proceedings of the eighth international space syntax symposium, eds Margarita Greene, José Reyes and Andrea Castro, 8105: 1-14 Santiago: Chile: PUC.

Liebst, Lasse. S. 2014. Staged, yet Unstaged : Sociological Inquiries into Space and Microinteraction. $\mathrm{PhD}$ diss., University of Copenhagen.

Liebst, Lasse. S. 2016. Reassembling Durkheimian sociology of space. In Spatial cultures: towards a new social morphology of cities past and present, eds Sam Griffiths and Alexander von Lünen, 214-224. London and New York: Routledge.

Litten, Julian. 1998. The English funeral 1700-1850. In Grave concerns: death and burial in England 1700-1850, ed. Margaret Cox, 3-16. York: CBA.

MacDonald, Julia. 1997. The Cutlers' Feast. In Mesters to masters: a history of the company of cutlers in Sheffield., eds, Clyde Binfield and David Hey, 225-240. Oxford: Oxford University Press.

Mayne Alan, and Tim Murray, eds. 2001. The archaeology of urban landscapes: Explorations in slumland. Cambridge: Cambridge University Press.

Mumford, Lewis. 1961. The City in History. Harmondsworth: Penguin. 
Nejad, Reza M. 2013. The discursive manifestation of past and present through the spatial organization of the Ashura procession. Space and Culture. Accessed April 7, 2015. DOI: $10.1177 / 1206331213475747$.

Netto, Vinicius. 2016. 'What is space syntax not?' Reflections on space syntax as sociospatial theory. Urban Design International 21, no. 1: 25-40.

Parkin, David. 1992. Ritual as spatial direction and bodily division. In Understanding Ritual. ed. Daniel de Coppet, 11-25. London and New York: Routledge.

Penn, Alan. 2003. The shape of habitable space'. In Proceedings 4th International Space Syntax Symposium, ed. Julienne Hanson, 62.1-62.16. London: University College London.

Peponis, John. 1985. The Spatial Culture of Factories. Human Relations 38, no. 4: 357-390.

Pooley, Colin. 2000. Patterns on the ground: urban form, residential structure and the social construction of space. In Martin J. Daunton, ed. The Cambridge urban history of Britain 1840-1950. Vol 3, 429-465. Cambridge: Cambridge University Press.

Shove, Elizabeth, Mika Pantzar and Matt Watson. 2012. The dynamics of social practice: everyday life and how it changes. Los Angeles: Sage.

Soja, Edward.W. 2001. In different spaces: Interpreting the spatial organization of societies. In: Proceedings of the Third International Space Syntax Symposium, eds, John Peponis, Jean Wineman, and Sonit Bafna, 1.1-1.7. Atlanta, U.S.A: Georgia Institute of Technology.

Smith, Dennis. 1982. Conflict and compromise: Class formation in English society 18301914: A comparative study of Birmingham and Sheffield. London: Routledge, Kegan and Paul.

Turner, Victor. W. 1966. The ritual process: structure and anti-structure. London Routledge, Kegan and Paul.

Urry, John. 2007. Mobilities. Cambridge, Polity. 
Vandeweghe, Evert. 2011. Staging urban history: festivities and the creation of historical townscapes in Belgium (1860-1958)." Environment, Space, Place 3, no.2: 122-160.

Vari, Alexander. 2013. The nation in the city: ceremonial (re)burials and patriotric mythmaking in turn-of-the-century Budapest. Urban History. Accessed February 182013. DOI 10. 1017/S0963926813000084

Weissenborn, Frederik. 2015. After structure: expression in built form. Journal of Space Syntax 6, no.1: 34-48.

Wood, Andy. 2014. The memory of the people: custom and popular senses of the past in early modern England.Cambridge and New York: Cambridge University Press. 